\title{
Fire resistance of wood treated with a cationic silica sol
}

\author{
Malte Pries $\cdot$ Carsten Mai
}

Received: 14 August 2012/Published online: 9 February 2013

(C) The Author(s) 2013. This article is published with open access at Springerlink.com

\begin{abstract}
Wood was treated with the cationic silica sol (CSS) Levasil 200S and dried at various temperatures (room temperature, 40, 60, 80 and $103{ }^{\circ} \mathrm{C}$ ). A water leaching test revealed fixation of the silica in wood even after drying at room temperature. Maximum cross sectional swelling of the specimens decreased from $15.6 \%$ (untreated control) to $13.0 \%$, when treated wood was dried at $103{ }^{\circ} \mathrm{C}$; cell wall bulking values were also negative $(-2.3 \%)$, indicating a thermal degradation of the cell wall polymers catalyzed by the CSS. Penetration of the CSS into the cell wall did not occur. A simple flammability test revealed increased fire resistance of the treated wood. Mass loss and velocity of mass loss as well as burning time were reduced; glowing of the formed charcoal was completely prevented. The effectiveness increased with increasing weight percent gain of the CSS in the wood. Thermo gravimetric analysis under nitrogen atmosphere displayed only minor reduction in the initial temperature of thermal decomposition for wood treated with CSS as compared to the control. In the presence of oxygen the resulting charcoal showed comparable thermal behaviour to the control. The yield of charcoal after pyrolysis was increased to a minor extent (from 19.9 to $23.0 \%$ ), indicating that the release of combustible gases was hardly reduced. The mode of action of enhanced fire resistance due to CSStreatment is discussed.
\end{abstract}

M. Pries · C. Mai $(\bowtie)$

Wood Biology and Wood Products, Burckhardt Institute,

Georg-August-University Göttingen, Büsgenweg 4,

37077 Göttingen, Germany

e-mail: cmai@gwdg.de

\section{Brandverhalten von mit kationisch modifiziertem Kieselsol behandeltem Holz}

Zusammenfassung Kiefernsplintholz wurde mit dem kationisch modifizierten Kieselsol Levasil 200S behandelt und bei verschiedenen Temperaturen getrocknet (Raumtemperatur, 40, 60, 80 und $103{ }^{\circ} \mathrm{C}$ ). Das Kieselsol war nach der Trocknung stabil gegenüber einer Auswaschung mit Wasser, selbst nach Trocknung bei Raumtemperatur. Die maximale Quellung der Querschnittsfläche des Holzes verringerte sich von 15,6\% (Kontrollen) auf 13,0\% bei behandeltem Holz, welches bei $103{ }^{\circ} \mathrm{C}$ getrocknet wurde. Die Querschnittsfläche im darrtrockenen Zustand verringerte sich ebenfalls (2,3\%), was auf einen thermischen Abbau des Holzes katalysiert durch das Kieselsol schließen lässt. Eine Eindringung des Sols in die Zellwand fand nicht statt. Ein einfacher Brandversuch zeigte erhöhte Feuerresistenz des behandelten Holzes. Der Gesamtmasseverlust, die Geschwindigkeit des Masseverlusts als auch die Brenndauer wurden reduziert. Das Nachglühen der entstandenen Holzkohle wurde komplett unterbunden. Die Wirkung stieg mit steigender Beladung des Holzes mit dem Kieselsol. Eine thermogravimetrische Analyse (TGA) unter Stickstoffatmosphäre ergab nur eine sehr geringe Abnahme der Pyrolysetemperatur. Die anschließende Verbrennung der entstandenen Holzkohle in Anwesenheit von Sauerstoff verlief vergleichbar zu den Kontrollproben. Die Holzkohleausbeute nach der Pyrolyse wurde durch die Behandlung nur leicht erhöht (von 19,9\% auf 23,0 \%), die Freisetzung von brennbaren Gasen aus dem Holz wurde dementsprechend unwesentlich verringert. Der Wirkungsmechanismus des kationischem Kieselsols auf das Brandverhalten des behandelten Holzes wird diskutiert. 


\section{Introduction}

Wood is a widely used building material which has, besides many advantages such as high weight-to-strength ratio, good insulating properties and favoured appearance, some natural drawbacks in use. The most important drawbacks are water related. Wood swells and shrinks under the conditions of changing ambient humidity. If unbound, liquid water is present in wood, fungal degradation can occur; insects can even destroy wood under dry conditions. Another important issue is the flammability of wood. Several attempts have been made to overcome these disadvantages; recently wood modification techniques such as acetylation, heat treatment or furfurylation have entered the market of biocide-free wood treatments (Hill 2006).

Wood is usually pressure impregnated with fire retardants, mostly inorganic salts such as mono/diammonium phosphate, ammonium sulfate, zinc chloride, sodium tetraborate and boric acid (White and Dietenberger 2010). Fire retardants can be divided into six different classes based on their modes of action, although most fire retardants operate via several mechanisms (Rowell and LeVanGreen 2005). They can, for example, increase charring of wood at lower temperature and, thus, form an insulating layer of non-flammable charcoal. In addition, they often have the side effect of diluting the flammable gases with non-combustible gases (e.g. ammonia gas from ammonium phosphate) and increasing the amount of resulting charcoal; the latter results in a diminished formation of combustible gases. Most of the fire retardant salts are not stable towards leaching out with water and can, therefore, only be used for materials used indoor. Coatings, which form insulating layers, constitute another class of fire protection agents. These coatings protect the wood by rapidly building up a thick insulating foam layer when exposed to temperatures between 180 and $200{ }^{\circ} \mathrm{C}$ (Scheer and Peter 2009). Silicon materials have long been used as fire retardants. Water glass was found to render wood fire resistant as early as 1825 (Fuchs 1825). It was later used as cheap short-term protection coating against fire especially in already erected buildings where pressure impregnation is not possible (Metz 1942). Water glass coating protects wood against fire by melting and forming an insulating foam layer on the surface of wood. Unfortunately, the water glass coating is not long-term stable due to neutralization in contact with air, which results in reduced foam formation and detachment of the coating from the substrate. Other silicon compounds have also been used to improve fire resistance of wood. Wood treated with inorganic composites based on tetraethoxysilane exhibited enhanced fire resistance (Saka et al. 1992); combination of tetraethoxysilane with trimethylphosphit/-borate led to further increase (Miyafuji and Saka 1996). Silica sols are another group of inorganic silicon compounds. They are produced by controlled removal of alkali from water glass through ion exchange techniques. This causes the silicic acid to polymerize and to form particles of amorphous silicon dioxide. To obtain a sol of polysilicic acid molecules, this polycondensation process is stopped at a certain stage by addition of alkali (Römpp 2001). Unmodified silica sols are therefore, alkaline and the colloids are stabilized by negative charge. Acidification of these sols leads to protonation of $\mathrm{Si}-\mathrm{O}$ anions and precipitation of the silica particles from the colloid. Sols can be stabilized sterically through modification of the colloid particle surface (e.g. with silanes) or by introducing positive charge (cationic groups). These modified sols are also stable under neutral or acidic conditions (Greenwood 2010). Silica sols have previously been used to impregnate wood (Böttcher et al. 1999; Götze et al. 2008; Temiz et al. 2006) in order to enhance resistance to fungi and water related properties. Influence on fire resistance has not been examined.

In a recent study, the use of various silica sols to protect wood against fungal colonization and water uptake was examined and significant improvements were found only with a cationic sol, which is modified with aluminiumoxychloride (Pries and Mai 2012). This study focuses on the fire resistant properties of wood modified with this CSS.

\section{Experimental}

\subsection{Materials}

Pine sapwood (Pinus sylvestris L.) specimens were cut from straight grained wood free of knots. Specimens to test anti-shrink-efficiency (ASE) had the dimensions $20 \times$ $20 \times 10 \mathrm{~mm}^{3}(\mathrm{~T} \times \mathrm{R} \times \mathrm{L})$, those to test fire resistance measured $13 \times 4 \times 125 \mathrm{~mm}^{3}(\mathrm{~T} \times \mathrm{R} \times \mathrm{L})$; growth rings were oriented $45^{\circ}$ with the tangential surface.

The silica sol used was Levasil 200S (Akzo Nobel, Düren, Germany) with a solid content of $30 \%$ and a pH of 3.7. Its surface is cationically modified with aluminium oxychloride; the counter ions of the cationic surface are chloride ions (Fig. 1).

Impralit F3/66 (Rütgers Organics, Mannheim, Germany), a commercial fire retardant, was used as a reference.

\subsection{Treatment of wood}

For impregnation, the specimens were placed in a desiccator and a vacuum of 7 mbar absolute pressure was applied for $15 \mathrm{~min}$. Subsequently, the solution was injected and the vacuum released. The specimens were left in the 


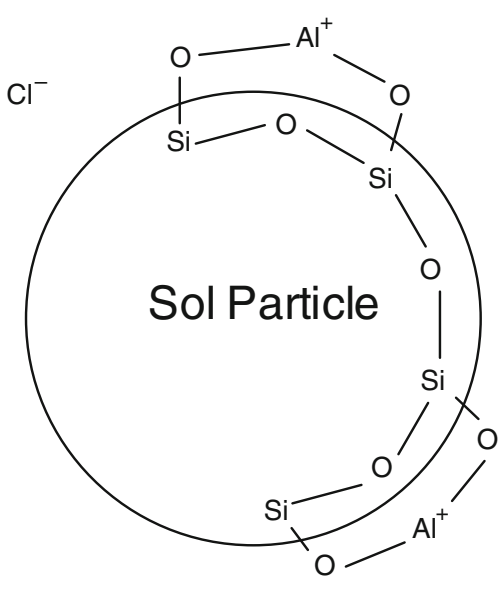

Fig. 1 Idealized cationic silica sol particle modified with aluminium oxide

Abb. 1 Idealisierter, mit Aluminiumoxychlorid modifizierter Kieselsolpartikel

solution for $2 \mathrm{~h}$ and subsequently dried as described below. The specimens were weighed after impregnation and drying to assess solution uptake and weight percent gain (WPG).

\subsection{Fixation of chemical}

ASE specimens were treated with $15 \%$ solutions (w/w) of Levasil 200S as described above. After treatment they were pre-dried at room temperature for 5 days. Subsequently eight specimens at a time were exposed to different temperatures for 3 days. The temperatures were: room temperature, 40, 60, 80 and $103{ }^{\circ} \mathrm{C}$. After this treatment the specimens were leached in water according to EN 84 (1997) and afterwards dried at room temperature and subsequently at $103{ }^{\circ} \mathrm{C}(24 \mathrm{~h}$ each $)$.

\subsection{Water uptake}

The eight ASE specimens dried at defined temperatures (fixation test) were submerged in $300 \mathrm{ml}$ water and weighted after 2, 4, 6 and $24 \mathrm{~h}$ of submersion time. After the last weighing a vacuum of approximately 40 mbar was applied for $1 \mathrm{~h}$. The specimens were left in the water for another day to ensure maximum water uptake. Water uptake was calculated based on the dry weight of the specimens before treatment (thus influence of the weight percent gain was eliminated).

\subsection{Weight percent gain (WPG), cell wall bulking} and maximum swelling

WPG and cell wall bulking (volume increase of the specimens in the dry state after chemical modification) were calculated according to the following formulas with all measurements taken in an oven dry state:

$$
\begin{aligned}
& \text { Bulking }(\%)=\frac{\operatorname{rad}_{\text {After treatment }} * \tan _{\text {After treatment }}}{\operatorname{rad}_{\text {Before treatment }} * \tan _{\text {Before treatment }}}-1 \\
& \text { WPG }(\%)=\frac{\text { Weight }_{\text {After treatment }}}{\text { Weight }_{\text {Before treatment }}}-1
\end{aligned}
$$

where "rad" is radial lengths and "tan" tangential lengths of the ASE specimens.

Maximum cross-sectional swelling was calculated from the dimensions of the fully saturated specimens of the water uptake test.

\subsection{Fire resistance}

The wood specimens were treated with 5, 10, and $15 \%$ solutions (w/w) of Levasil 200S as described above. After impregnation, the wood specimens were dried at room temperature and subsequently at $103{ }^{\circ} \mathrm{C}(24 \mathrm{~h}$ each $)$. As a reference, wood specimens were treated in the same way with a solution $(10 \%, \mathrm{w} / \mathrm{w})$ of the commercial fire retardant Impralit F3/66 (Rütgers Organics, Mannheim, Germany). Ten replicates for each treatment were used. Prior to fire resistance testing, they were conditioned at $20{ }^{\circ} \mathrm{C}$ and $65 \% \mathrm{RH}$; water leaching was not performed.

The specimens were clamped into a holder at one end forming an angle of $45^{\circ}$. The specimen holder was placed on a balance in a way that the specimen was hanging down next to the scale. The balance was tarred before clamping the specimen. From the starting mass of the specimens, the moisture content based on the original dry mass of the wood (before treatment) was calculated.

The specimens' tip was ignited with a Bunsen burner for $30 \mathrm{~s}$. In doing so the flame of the Bunsen burner was always equal in height and strength for all specimens. The weight of the specimen was recorded in $10 \mathrm{~s}$ intervals; at the same time it was assessed whether the specimen was burning or glowing. The mass loss of the specimens was related to the original dry weight (before treatment) and depicted as a function of experimental time. Total mass loss, maximum mass loss per ten-second interval (burning rate), burning time and glowing time were calculated. The test was repeated, when the specimen broke during testing.

\subsection{Thermo-gravimetric analysis (TGA)}

The treated and control specimens were milled with a centrifugal mill using a mesh of $0.5 \mathrm{~mm}$ (Retsch ZM 100, Retsch, Germany). TGA was performed using Netsch TG209 F1 IRIS (Selb, Germany); approximately $10 \mathrm{mg}$ were weighted in aluminium-oxide crucibles. The temperature program is specified in Table 1 . The flow rate of 
Table 1 Temperature program of the thermogravimetric analysis (TGA)

Tab. 1 Temperaturprogramm der thermogravimetrischen Analyse (TGA)

\begin{tabular}{lllcccc}
\hline $\begin{array}{l}\text { Segment } \\
\text { No. }\end{array}$ & Type & $\begin{array}{l}\text { Final temperature } \\
\left({ }^{\circ} \mathrm{C}\right)\end{array}$ & $\begin{array}{l}\text { Slope } \\
\left(\mathrm{K} \mathrm{min} \mathrm{min}^{-1}\right)\end{array}$ & $\begin{array}{l}\text { Time } \\
(\mathrm{min})\end{array}$ & $\begin{array}{l}\text { Oxygen purge gas } \\
\left(\mathrm{ml} \mathrm{min}^{-1}\right)\end{array}$ & $\begin{array}{l}\text { Nitrogen purge gas } \\
(\mathrm{ml} \mathrm{min}\end{array}$ \\
\hline 1 & Dynamic & 100 & 20 & 4 & 0 & 50 \\
2 & Isothermal & 100 & - & 5 & 0 & 50 \\
3 & Dynamic & 550 & 10 & 55 & 0 & 50 \\
4 & Isothermal & 550 & - & 5 & 0 & 50 \\
5 & Dynamic & 250 & -40 & 7.30 & 0 & 50 \\
6 & Isothermal & 250 & - & 5 & 0 & 50 \\
7 & Dynamic & 650 & 20 & 20 & 10 & 40 \\
8 & Isothermal & 650 & - & 5 & 10 & 40 \\
\hline
\end{tabular}

the nitrogen protective gas was $20 \mathrm{ml} \mathrm{min}^{-1}$ in each segment (Table 1).

A measurement with an empty crucible served as correction curve, which was subtracted from the sample measurements. Onset and end of the mass loss curves (Fig. 6a, b) as well as the maximum of the first derivative were recorded. The mass losses at the various segments of the program were recorded as absolute weight. To determine the percentage mass loss of the two mass loss steps (step 1: segment 3; step 2: segment 7, Table 1), all curves were shifted in a way that the final point of the thermograms was equal to the ash content of the control specimen $(0.84 \%)$. In doing so the influence of the silica add-on in the specimens, i.e., the WPG, was avoided. In order to allow for direct comparison of the percentage weight losses of all treated specimens, the starting point for the calculations ( $0 \%$ mass loss) was the begin of the 3 rd segment. In the 1 st and 2nd segment the specimens were only dried to exclude any effects of different moisture content.

\section{Results and discussion}

\subsection{Fixation of chemical}

Irrespective of the drying temperature, the weight percent gains (WPG) of CSS-treated specimens after leaching were equal (Fig. 2). This revealed that the drying temperature did not have an effect on the stability of the silica towards water leaching, when the drying time is sufficient. The treatment, which actually resulted in lowest mean value, was the treatment at $103{ }^{\circ} \mathrm{C}$ (Fig. 2).

While silica particles in sols form a colloidal solution, they agglomerate in wood upon drying and form insoluble condensation products which are apparently stable to water leaching. This process does not require elevated temperatures.

It has been suggested to fix silica in wood by covalent bonding in order to increase leaching stability of tetraethoxysilane (Ogiso and Saka 1994); this, however, is

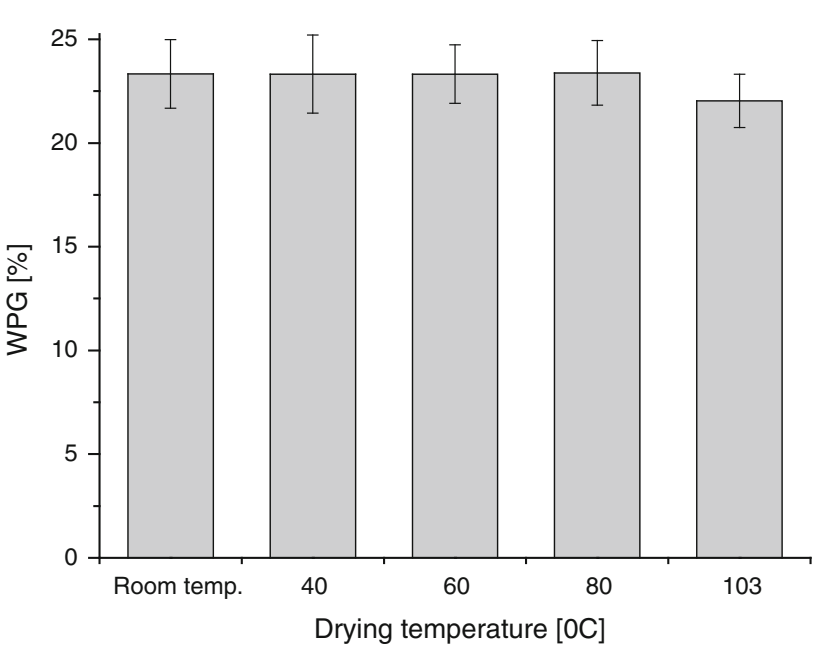

Fig. 2 WPG of ASE specimens after water leaching as a function of various temperatures; mean values and standard deviations

Abb. 2 WPG der ASE-Proben nach der Auswaschung mit Wasser in Abhängigkeit der Trocknungstemperatur nach der Behandlung; Mittelwerte und Standardabweichungen

apparently not necessary for silica sol-treatment. Water glass has also been used to treat wood and was always found to be unstable towards water leaching (Furuno et al. 1992; Matthes et al. 2002). The reason for the high solubility in water is the high content of alkali in water glass, which forms anionic silanolate groups. Water glass can be precipitated by addition of acids or by divalent ions. In wood this is achieved by ambient carbon dioxide which forms carbonic acid and causes protonation of the silanolate groups. The cationic colloid particles of the CSS used in this study, on the other hand, are only stabilized by small addition of chloride ions and are directly insoluble upon drying.

\subsection{Water uptake}

Treatment with CSS significantly decreased velocity of water uptake. Mean values of water uptake were lower for specimens, which were dried at higher temperatures (Fig. 3). Although the variation of water uptake was high, a 


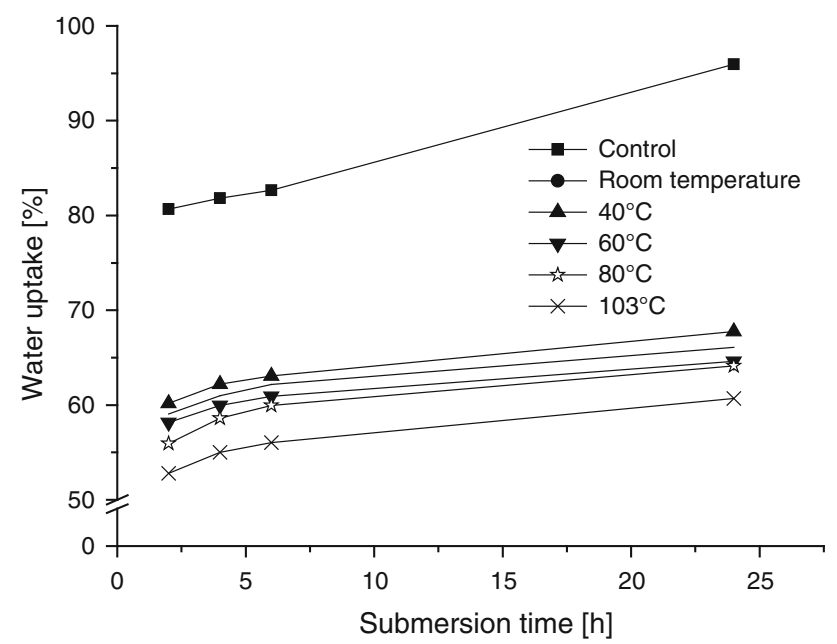

Fig. 3 Water uptake of untreated and CSS-treated wood specimens dried at various temperatures (mean values)

Abb. 3 Wasseraufnahme der Kontrollen und der mit kationischem Kieselsol behandelten Prüfkörper, welche bei verschiedenen Temperaturen getrocknet wurden (Mittelwerte)

$t$ test revealed, that the water uptake of the specimens dried at $103{ }^{\circ} \mathrm{C}$ was significantly lower (significance level 0.05 ) for the points at 4,6 and $24 \mathrm{~h}$ as compared to the specimens dried at room temperature and it was always significantly lower than water uptake of specimens dried at $40{ }^{\circ} \mathrm{C}$. Silica usually is a hydrophilic material and is therefore not expected to render wood water repellent. Especially, water glass has been reported to increase hygroscopicity of the treated wood. This was explained by the hygroscopic salts (silanolate and alkali ions) left in the wood after treatment (Furuno et al. 1992; Matthes et al. 2002). Silica sol on the other hand has previously shown to reduce water uptake. Treatment of spruce wood samples with silica sols reportedly reduced water uptake by approx. $25 \%$ after 6 days of water immersion (Götze et al. 2008). Wood treated with alkaline silica sols of two different particle sizes, 15 and $30 \mathrm{~nm}$, showed reduction in water uptake; the bigger particle size resulted in lower water uptake (Temiz et al. 2006).

It can be concluded, that the CSS Levasil 200S is better suited for reducing water uptake of wood than water glass. This can be explained by the much lower surface charge and respective lower content of counter ions in silica sols as compared to water glass. CSS reduces capillary water uptake probably by partial blocking of the main penetration paths for water such as ray cells and tracheids (Pries and Mai 2012).

\subsection{Cell wall bulking and maximum swelling}

The cross-sectional area of the specimens after treatment with CSS was lower than before treatment; thus cell wall bulking was negative. The higher the drying temperature, the

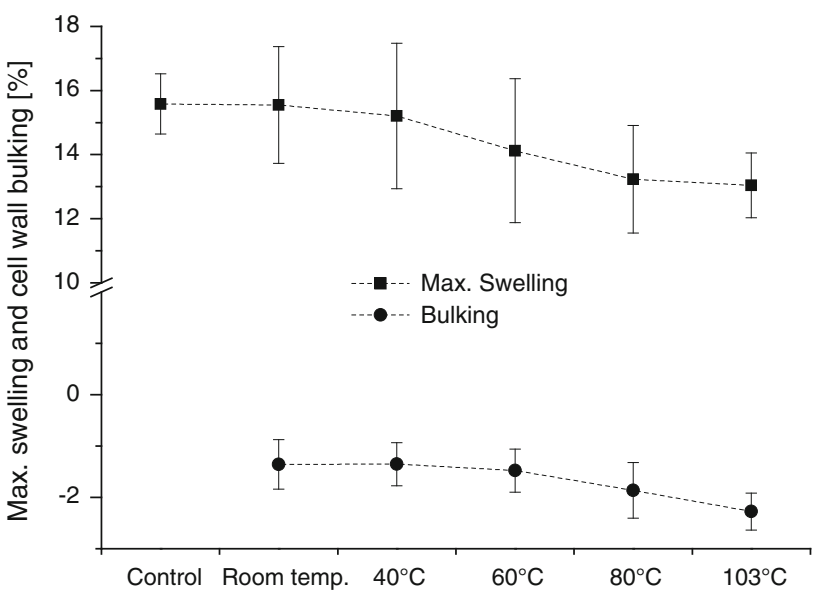

Fig. 4 Maximal cross-sectional swelling and cross-sectional bulking of specimens treated with CSS and dried at various temperatures; mean values and standard deviations

Abb. 4 Maximale Quellung der Querschnittsfläche sowie das Bulking von mit kationischem Kieselsol behandelten Prüfkörpern in Abhängigkeit der Trocknungstemperatur nach der Behandlung; Mittelwerte und Standardabweichungen

more negative was the bulking. Bulking of specimens dried at $103{ }^{\circ} \mathrm{C}$ was significantly lower than bulking of specimens dried at room temperature, 40 and $60{ }^{\circ} \mathrm{C}$ (Fig. 4). Maximum swelling in water also decreased with increased drying temperature. While the control and specimens dried at room temperature showed maximum cross-sectional swelling of approx. $15.5 \%$, specimens dried at $103{ }^{\circ} \mathrm{C}$ displayed only a mean maximum swelling of $13.0 \%$; the latter was significantly lower than the former. This is attributed mostly to the hydrolysis of hemicelluloses, which are the most susceptible wood polymers to hydrolysis (Stamm 1964), because bound aluminium chloride in Levasil 200S may act as a Lewis acid (Pries and Mai 2012).

Acid releasing chemicals can be used as fire retardants, because they induce charring of wood at low temperatures and thus form an insulating layer at the surface (White and Dietenberger 2010). CSS might therefore, act in the same way by reducing the degradation temperature of wood constituents in case of fire and thereby rendering the wood more fire retardant.

\subsection{Fire resistance and thermo-gravimetric analysis (TGA)}

The weight percent gain (WPG) of the specimens treated with CSS in the concentrations of 5,10 and $15 \%$ were 8.8, 17.2, and $27.6 \%$, respectively. Treatment with the commercial fire retardant Impralit F3/66 resulted in a WPG of $11.2 \%$.

The moisture content of the CSS-treated specimens $(12.9,15 \%$ CSS $)$ was somewhat higher than that of the controls $(11.4 \%)$. Specimens treated with the fire retardant 
were even more hygroscopic and displayed a moisture content of $14.4 \%$ (Fig. 5a).

The fire resistance test revealed a strong reduction in the maximum burning rate as compared to the untreated control (Fig. 5b). The burning rate usually reached its maximum right after removing the Bunsen burner. While the control specimens lost approx. $8.4 \%$ per $10 \mathrm{~s}$, specimens treated with $15 \%$ CSS showed only a maximum mass loss rate of $3.8 \%$ per $10 \mathrm{~s}$. Treatment with the fire retardant caused the lowest burning rate of $2.2 \%$ per $10 \mathrm{~s}$. Parallel to this reduction in the burning rate, a strong reduction in total mass loss occurred, because the treated specimens did not burn completely. While the mass loss of the controls amounted to approx. $80 \%$, specimens treated with $15 \%$ CSS underwent only a mass loss of $20 \%$; specimens treated with the fire retardant lost only $13 \%$ of their mass.

The control specimens burned completely with a mean burning time of approx. $120 \mathrm{~s}$. After burning, the specimens continued to glow with a mean glowing time of $80 \mathrm{~s}$. All treated specimens ceased to burn before complete burning of the specimen and none of the treated specimens
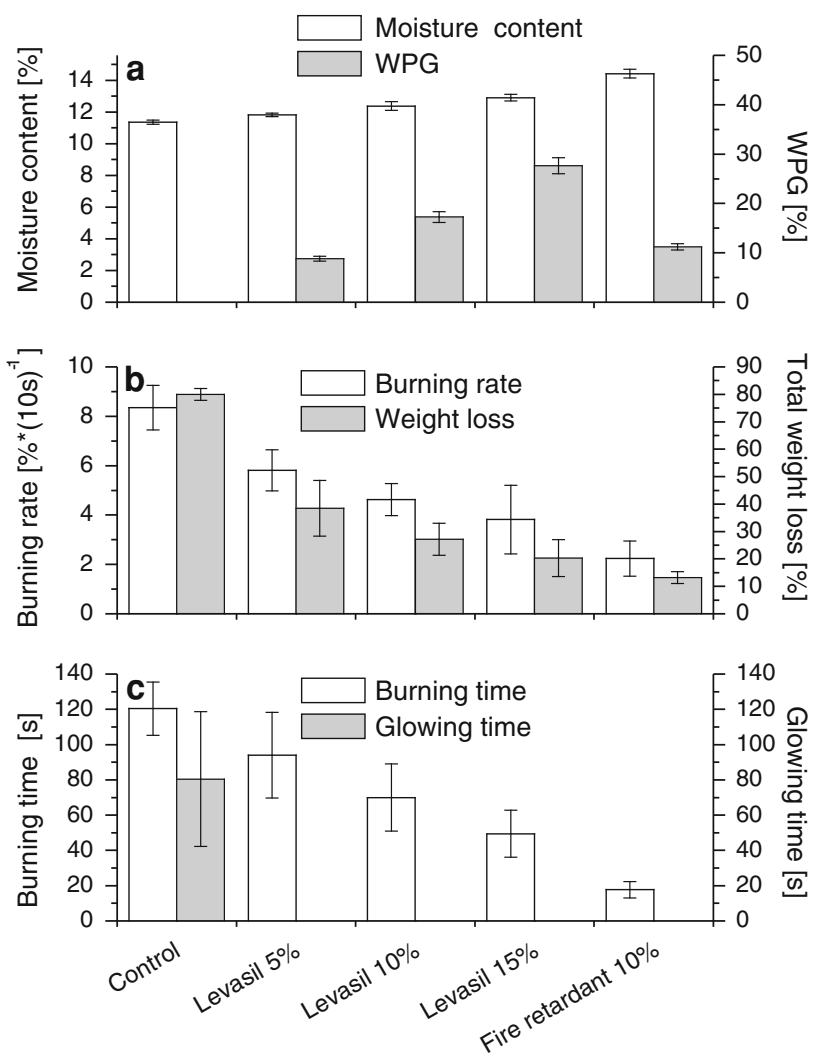

Fig. 5 Results of a burning test of untreated, CSS-treated and wood treated with a commercial fire retardant; (mean values and standard deviations) Abb. 5 Ergebnisse eines Brandversuchs der Kontrollen, der mit kationischem Kieselsol sowie der mit einem kommerziellen Feuerschutzsalz behandelten Proben; Mittelwerte und Standardabweichungen exhibited any glowing after extinction of the fire. Mean burning time of specimens treated with $15 \%$ CSS amounted to $49 \mathrm{~s}$, while specimens treated with the fire retardant burned only $18 \mathrm{~s}$.

Fire retardance of wood by chemicals can be indicated in a TGA through a decrease of the initial temperature of pyrolysis and an increase of the amount of produced charcoal which indirectly indicates a reduction of volatile, combustible gases (Rowell and LeVan-Green 2005). In the present study, TGA revealed only minor differences in the pyrolysis behaviour between the control and CSS-treated wood. The onset of mass loss in the pyrolysis of CSStreated wood was at slightly lower temperature $\left(294.4^{\circ} \mathrm{C}\right)$ than of the control $\left(304.0^{\circ} \mathrm{C}\right)$. The temperature of maximal mass loss per time (maximum of first derivative) was also shifted from $353.5{ }^{\circ} \mathrm{C}$ (control) to $339.7{ }^{\circ} \mathrm{C}$ (15\% CSS). Wood treated with the fire retardant showed an onset of pyrolysis at $264.7{ }^{\circ} \mathrm{C}$ and a temperature of maximum mass loss per time at $291.9^{\circ} \mathrm{C}$ (Figs. 6a, 7a).

After the pyrolysis, the resulting charcoal was burned in the presence of oxygen (Figs. 6b, 7a). The burning behaviour of charcoal from CSS-treated wood was very similar to that of the control. While the onset of burning in case of the control was at $438.9{ }^{\circ} \mathrm{C}$ and the maximum mass loss per time at $491.1{ }^{\circ} \mathrm{C}$, the respective points for wood treated with $15 \% \mathrm{CSS}$ were at 438.9 and $486.1^{\circ} \mathrm{C}$. The coal from wood treated with the fire retardant showed higher fire resistance with an onset at $461.7^{\circ} \mathrm{C}$ and a temperature of maximum mass loss at $522.5^{\circ} \mathrm{C}$ (Fig. 7a). The remaining charcoal is an important measure of how much burnable gas was released during pyrolysis. Charcoal yield increased only very slightly due to treatment with CSS. While the control yielded $19.9 \%$ charcoal, wood treated with $15 \%$ CSS yielded $23.0 \%$. Wood treated with the fire retardant increased the charcoal yield to $34.4 \%$ (Fig. 7b).

TGA revealed only a slight downshift of pyrolysis temperature of CSS-treated wood as compared to the control, while treatment with the commercial fire retardant resulted in strongly reduced pyrolysis temperature. Pyrolysis of wood at lower temperature can be due to acidic reaction of the fire retardant. Proton donators and Lewis acids such as zinc chloride or aluminium chloride can lower the initial temperature for thermal decomposition, which can lead to the formation of an insulating charcoal layer. Aluminium chloride has been used as a fire retardant, the performance, however, was not good enough for wider usage (Kollmann 1951; Metz 1942).

The reduction of combustible volatiles is another important feature of fire retardants. This includes the inhibition of formation of levoglucosan a breakdown product of cellulose (Rowell and LeVan-Green 2005). A reduction of combustible volatiles is shown by a high 

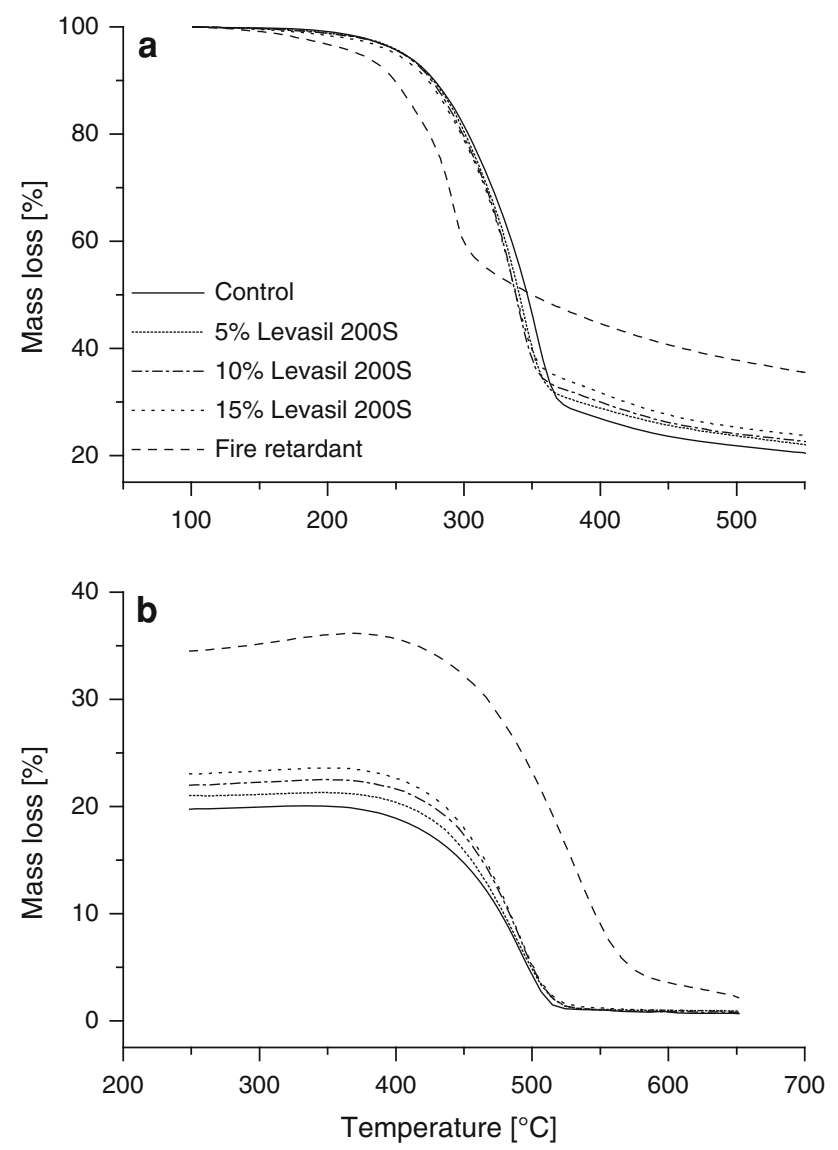

Fig. 6 Mass loss curves (thermo-gravimetric analysis) of untreated, CSS-treated and wood treated with a commercial fire retardant under nitrogen atmosphere (a segment 3 in Table 1) and subsequent burning of the resulting charcoal in the presence of oxygen (b segment 7 in Table 1)

Abb. 6 Kurven des Masseverlustes der Kontrollen, der mit Kieselsol behandelten sowie der mit einem kommerziellen Feuerschutzsalz behandelten Proben in der thermogravimetrischen Analyse: Unter Stickstoffatmosphäre (a Segment 1 in Tabelle 1) und anschließende Verbrennung der entstandenen Holzkohle in Anwesenheit von Sauerstoff (b Segment 7 in Tabelle 1)

charcoal yield after pyrolysis. In contrast to the fire retardant, the CSS only increased the charcoal yield to a minor extent and thus did hardly reduce the amount of combustible gases. The resulting charcoal of CSS-treated wood showed the same burning behaviour as the charcoal of the control.

The relatively strong fire retardance revealed in the burning test can be explained by several effects, which are not reflected in the TGA. The formation of a charred layer at lower temperatures is mentioned above. Another reason might be the increased density, which causes a higher heat capacity. As a consequence, more energy is needed to heat the wood to a temperature where combustible gases are released (Metz 1942).

Incorporation of CSS into the wood lumens might also hinder the release of volatile gases and thus reduce the combustibility. When wood is heated, combustible gases
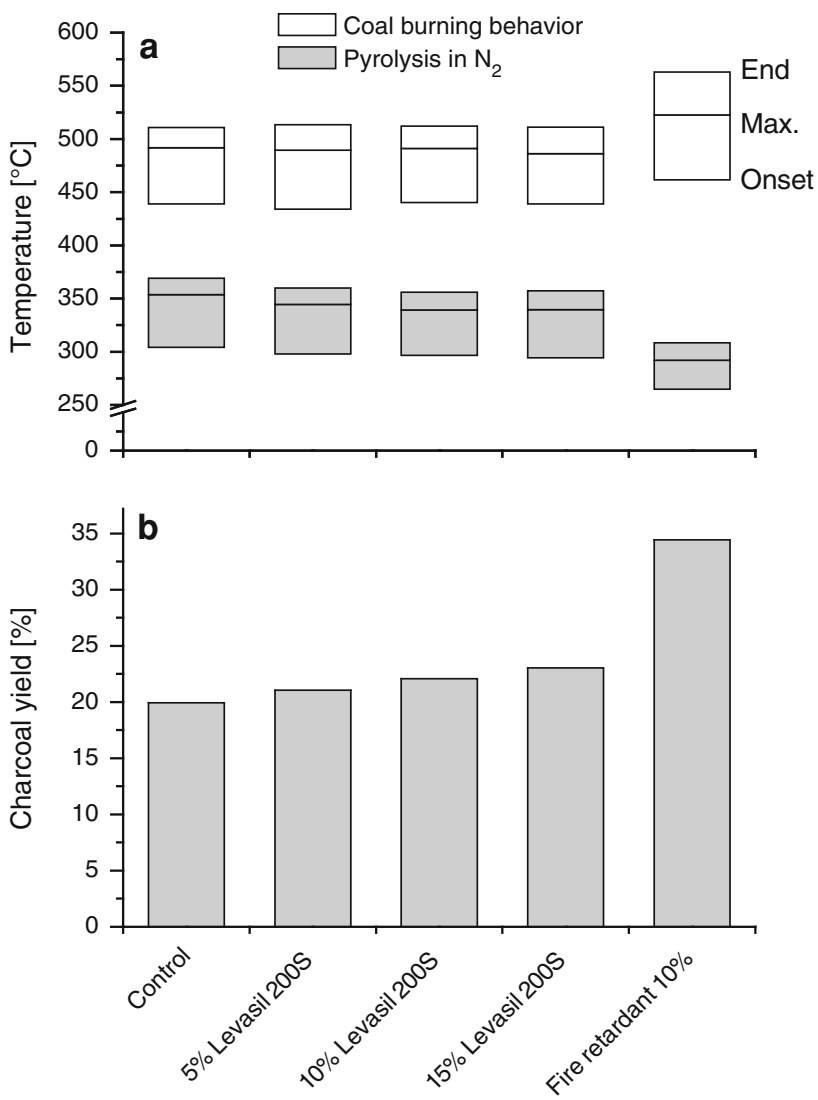

Fig. 7 Onset of mass loss, temperature of fastest mass loss and end of mass loss (a) as well as char coal yield (b) of untreated wood and wood treated with silica sol and a commercial fire retardant in the TGA under nitrogen atmosphere

Abb. 7 Beginn des Masseverlusts, Temperatur des schnellsten Masseverlustes und Ende des Masseverlusts (a) sowie Holzkohleausbeute (b) der Kontrollen, der mit Kieselsol sowie der mit Feuerschutzsalz behandelten Proben in der thermogravimetrischen Analyse unter Stickstoffatmosphäre

are released from the cell wall and exit the wood structure through the lumen to burn outside the wood. It was found that diffused porous wood burns better than ring porous wood, because the homogenous distribution of vessels facilitates diffusing of the gases to the wood surface. Ring porous wood on the other hand shows worse burning behaviour, because most vessels are small and hinder the gases from exiting. The same is true for the very small tracheids of many soft woods (Metz 1942).

CSS treatment might also influence the porosity of charcoal formed during pyrolysis. Especially the charcoal from diffused porous wood glows easier, because air has better access to the charcoal. Nonporous charcoal cannot be easily penetrated by air and the dangerous after-glowing is prevented (Metz 1942). None of the treated wood specimens exhibited any glowing after the fire stopped; this indicates that the charcoal was less porous and, therefore, air was not able to enter properly. 
Another mode of action could be that silica sol incorporated into the lumen might increase the thermal conductivity of the wood. This might lead to increased fire retardance because the wood cannot be heated up locally as easily as untreated one and thus does not inflame as fast (Metz 1942).

High moisture content due to the incorporation of hygroscopic chemicals into the wood might be another reason. The increase in moisture content of CSS-treated wood, however, was so minor that this effect was ruled out.

Effects of silicon compounds on fire resistance of wood have mainly been studied with tetraethoxysilane (TEOS) and mixtures of it. TEOS treatment alone increased fire resistance (Saka et al. 1992). This effect was enhanced by combining TEOS with trimethylphosphit and/or trimethylborate in a burning test similar to the test done in this study (Miyafuji and Saka 1996). The chemicals used by Miyafuji and Saka (1996), however, were located in the cell walls (positive bulking and ASE was observed), while silica in this study was located only in the lumens.

\section{Conclusion}

Wood treatment with CSS decreased the maximum swelling of wood, when the treated wood was dried at $103{ }^{\circ} \mathrm{C}$. This was mostly attributed to the hydrolysis of hemicelluloses. Reduction of the initial degradation temperature upon heating is known to be one mode of action of fire retardants, because it leads to the formation of an insulating charcoal layer. Fire retardant properties of CSS-treated wood were demonstrated in a simple burning test, while TGA only revealed minor changes as compared to untreated wood. CSS treatment can increase fire retardancy of wood but in general the effect is minor compared to the commercial fire retardant tested. Still, treatment of wood with CSS at $15 \%$ concentration improves some important wood properties such as low capillary water uptake and resistance to decay fungi. Increased fire retardancy, as shown in this study, is an additional positive effect of the treatment.

Open Access This article is distributed under the terms of the Creative Commons Attribution License which permits any use, distribution, and reproduction in any medium, provided the original author(s) and the source are credited.

\section{References}

Böttcher H, Jagoda C, Trepe J, Kallies KH, Haufe H (1999) Sol-gel composite films with controlled release of biocides. J Control Release 60:57-65

EN 84 (1997) Wood preservatives-Accelerated ageing of treated wood prior to biological testing-Leaching procedure. European Committee for Standardisation (CEN), Brussels, Belgium

Fuchs JN (1825) Ueber ein neues Product aus Kieselerde und Kali; und dessen nüzzliche Anwendung als Schuzmittel gegen schnelle Verbreitung des Feuers in Theatern, als Bindemittel, zu firnißartigen Anstrichen u.s.w. Dinglers polytechnisches J 17:465-481

Furuno T, Shimada K, Uehara T, Jodai S (1992) Combinations of wood and silicate II. Wood-mineral composites unsing water glass and reactance of barium chloride, boric acid, and borax and their properties. Mokuzai Gakkaishi 38:448-457

Götze J, Mockel R, Langhof N, Hengst M, Klinger M (2008) Silification of wood in the laboratory. Ceram-Silikaty 52:268-277

Greenwood P (2010) Surface modifications and applications of aqueous silica sols. Dissertation, Gothenburg

Hill CAS (2006) Wood modification. Chemical, thermal and other processes. Wiley, Chichester

Kollmann F (1951) Technologie des Holzes und der Holzwerkstoffe, vol 2, 2nd edn. Springer, Berlin

Matthes R, Nehring HO, Dellith W (2002) Wasserglas-Holzschutz im Hochbau. Proc. "Integrierter Umweltschutz im Bereich der Holzwirtschaft" 22nd-24th of January 2002, Göttingen:104-108

Metz L (1942) Holzschutz gegen Feuer, 2nd edn. VDI-Verlag GmbH, Berlin

Miyafuji H, Saka S (1996) Wood-inorganic composites prepared by the sol-gel process. 5. Fire-resisting properties of the $\mathrm{SiO}_{2}-\mathrm{P}_{2} \mathrm{O}_{5}-\mathrm{B}_{2} \mathrm{O}_{3}$ wood-inorganic composites. Mokuzai Gakkaishi 42:74-80

Ogiso K, Saka S (1994) Wood-inorganic composites prepared by solgel process. 4. Effects of chemical bonds between wood and inorganic substances on property enhancement. Mokuzai Gakkaishi 40:1100-1106

Pries M, Mai C (2012) Treatment of wood with silica sols against attack by wood decaying fungi and blue stain. Holzforschung (in press)

Römpp (2001) Römpp Chemielexikon online, Thieme Chemistry, Stuttgart

Rowell RM, LeVan-Green SL (2005) Thermal properties. In: R M Rowell (ed.), Handbook of wood chemistry and wood composites, Taylor \& Francis, New York

Saka S, Sasaki M, Tanahashi M (1992) Wood-inorganic composites prepared by sol-gel processing I. Wood-inorganic composites with porous structure. Mokuzai Gakkaishi 38:1043-1049

Scheer C, Peter M (2009) Holz Brandschutz Handbuch (3 edn). Deutsche Gesellschaft für Holzforschung, Ernst \& Sohn, Berlin

Stamm AJ (1964) Wood and cellulose science. The Ronald Press Company, New York

Temiz A, Terziev N, Jacobsen B, Eikenes M (2006) Weathering, water absorption, and durability of silicon, acetylated, and heattreated wood. J Appl Polym Sci 102:4506-4513

White RH, Dietenberger MA (2010) Wood handbook, Chapter 18: fire safety of wood construction. Department of Agriculture, Madison 